\title{
Steric and Electronic Effects of Benzoferrocenyl Phosphine Ligands on Palladium-Catalyzed Allylic Alkylation and Suzuki Coupling Reactions
}

\author{
Muralidhara Thimmaiah, Rudy L. Luck and Shiyue Fang* \\ Department of Chemistry, Michigan Technological University, 1400 Townsend Drive, Houghton, MI 49931, USA
}

\begin{abstract}
Five benzoferrocenyl phosphine ligands with the phosphorus atom attached to the 5-position of the benzoferrocene and some ligand-Mo(CO $)_{5}$ complexes were prepared and fully characterized; the structure of one ligand was confirmed by X-ray crystallography. These ligands were applied in palladium-catalyzed allylic alkylation and Suzuki coupling of chlorobenzene with phenylboronic acid. Results were compared with those reported previously using ligands having the phosphorus atom attached to the 4-position of benzoferrocene. This structural modification resulted in an increase of activity of the ligands in allylic alkylation reaction but a decrease of activity in Suzuki coupling reactions. The underlying reasons are analyzed with the help of X-ray single crystal determined structures and $\mathrm{CO}$ stretching frequencies in the IR spectra of complexes between the ligands and $\mathrm{Mo}(\mathrm{CO})_{5}$.
\end{abstract}

Keywords: Benzoferrocene, Suzuki coupling, Allylic alkylation, Phosphine ligand, Catalysis.

\section{INTRODUCTION}

Transition metals such as palladium are widely used as catalysts in carbon-carbon and carbon-heteroatom bonds formation reactions and play a pivotal role in organic synthesis [1]. In homogeneous catalysis, the supporting ligand such as those based on tertiary phosphines has a critical influence on the activity of the catalyst; such an influence is generally analyzed as steric and electronic effects although the two from this exploration would allow us to select the most active targets for enantioselective preparation. In addition, a number of publications implied potential chemical and configurational instability of benzoferrocenes [4], characterization of more examples of these ligands would further demonstrate their suitability for catalysis. To this end, five novel ligands (2a-e) were prepared and fully characterized; in addition, the X-ray determined single crystal structure of $2 \mathbf{a}$ was obtained to confirm the proposed structure and for compari-

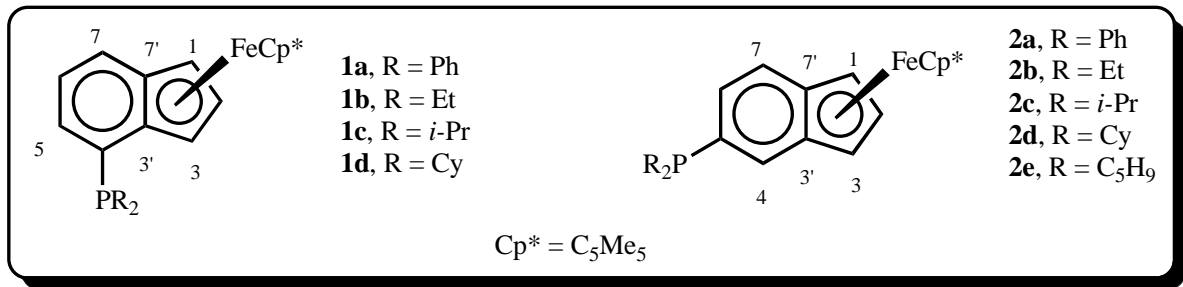

cannot be separated and they always affect each other [2]. Recently, we initiated a project to develop a new class of chiral benzoferrocenyl phosphine ligands and use them to solve some problems in enantioselective catalysis [3]. At the initial stage of the project, it was important to demonstrate the chemical and configurational stability of these ligands and their activity in transition metal-catalyzed reactions. Accordingly, we reported the synthesis and characterization of four such ligands (1a-d) and their applications in allylic alkylation and Suzuki coupling reactions [3]. We found that these ligands were indeed chemically and configurationally stable and some of them were highly active for these reactions. While making efforts to develop efficient methodologies for the preparation of these ligands in enantiopure form, we explored the steric and electronic effects of these ligands on their activity upon moving the phosphorus atom from the 4-position to the 5-position of benzoferrocene. The results

*Address correspondence to this author at the Department of Chemistry, Michigan Technological University, 1400 Townsend Drive, Houghton, MI 49931, USA; E-mail: shifang@mtu.edu son with that of 1a in analyzing the steric difference of the two sets of ligands (1a-d and 2a-e); furthermore the IR spectra of several ligand-Mo(CO $)_{5}$ complexes were measured for analyzing electronic character of the ligands. The ligands (2a-e) were utilized in palladium-catalyzed allylic alkylations and Suzuki coupling reactions. We found that having the phosphorus atom attached to the 5-position as opposed to the 4-position of benzoferrocene changed the steric and electronic effects of the ligands and these changes increased the activity of the ligands in allylic alkylation but reduced their activity in Suzuki coupling. The underlying reasons are analyzed with the help of the X-ray determined crystal structures of $1 \mathbf{a}$ and 2a, and the $\mathrm{CO}$ stretching frequencies in the IR spectra of the complexes 1- $\mathrm{Mo}(\mathrm{CO})_{5}$ and $2-\mathrm{Mo}(\mathrm{CO})_{5}$.

\section{RESULTS AND DISCUSSION}

The ligands 2a-e were prepared from commercially available 6-bromo-1 $(H)$-indene (3) in two steps (Scheme 1). To prevent debromination, the solution of $\mathbf{3}$ in THF was cooled to $-78{ }^{\circ} \mathrm{C}$ and then treated with $n$-BuLi followed by warming to rt slowly. This solution was then added dropwise 

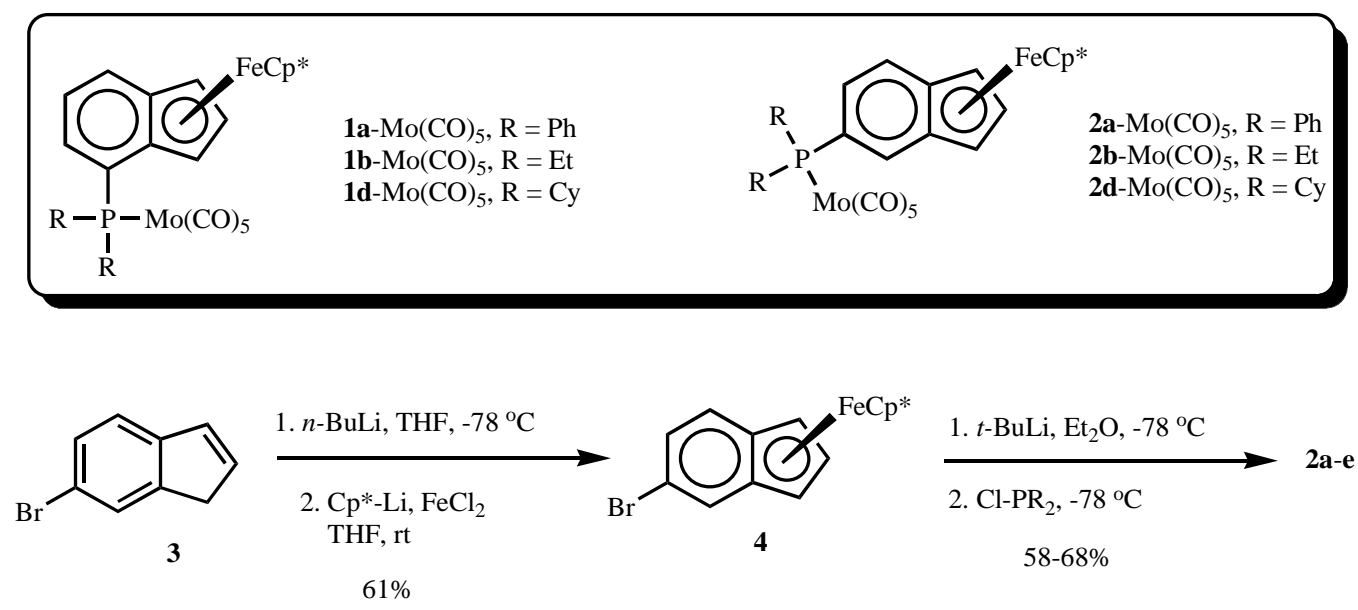

Scheme 1. Synthesis of benzoferrocenyl phosphine ligands 2a-e.

to a solution of $\mathrm{Cp}^{*}$ - $\mathrm{Fe}$ (II)-Cl in THF via cannula and the mixture stirred at rt for $3 \mathrm{~h}$. Aqueous workup and recrystallization from cold hexanes gave $\mathbf{4}$ in $61 \%$ yield as a crystalline solid. Exchange of the bromine atom on $\mathbf{4}$ with $t$-BuLi followed by treatment with $P$-chlorodiphenylphosphine (2a) or $P$-chlorodialkylphosphine (2b-e) gave the desired phosphine ligands in 58-68\% yields after aqueous workup and flash column chromatography purification. Similarly to the previously reported 1a-d [3b], pure 2a-e were stable in air at $\mathrm{rt}$; but in solution, they were slowly oxidized to the corresponding phosphine oxides as indicated in their ${ }^{31} \mathrm{P}$ NMR spectra. All compounds (4 and 2a-e) were fully characterized with ${ }^{1} \mathrm{H},{ }^{13} \mathrm{C}$ and ${ }^{31} \mathrm{P}$ (2a-e only) NMR spectra and elemental analyses or high resolution MS. The structure of 2a was confirmed with single crystal X-ray crystallography (Fig. 1). Attempts to resolve the enantiomers of 2a-e using chiral HPLC were unsuccessful under a variety of conditions including those that were used previously to resolve 1a,b [3b].

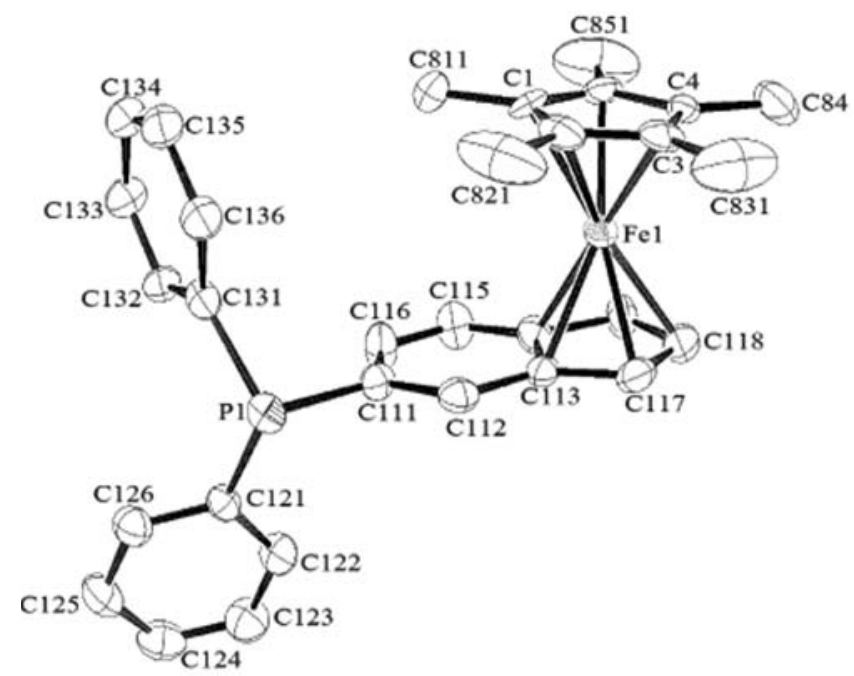

To test the stability of these ligands, $\mathbf{2 a}$ a,d were dissolved in hexane, $\mathrm{Et}_{2} \mathrm{O}$ and THF, respectively. The resulting solutions were stirred under nitrogen atmosphere at $\mathrm{rt}$ and at reflux, and were periodically analyzed with GC-MS; no decomposition was detected even after $48 \mathrm{~h}$ for both compounds. These ligands were stored in pure form under nitrogen at $0{ }^{\circ} \mathrm{C}$ for more than 6 months; no decomposition was detected by GCMS and NMR.

Compound 2a crystallized with two molecules in the asymmetric unit and both of these contained disorder in the position of the $\mathrm{Cp}^{*}$ ring. The crystal structure of $\mathbf{2 a}$ shows that the iron atom is coordinated to the 5-membered ring of indene in an $\eta^{5}$-fashion, and the distances between the iron and the five carbon atoms of the 5-membered ring are not identical as the ring is tilted upwards slightly and the iron atom is situated off center of the ring (Fig. 1). The carbon and hydrogen atoms of the indenyl moiety are nearly planar and the plane is almost parallel to that of the $\mathrm{Cp}^{*}$ (angle be-

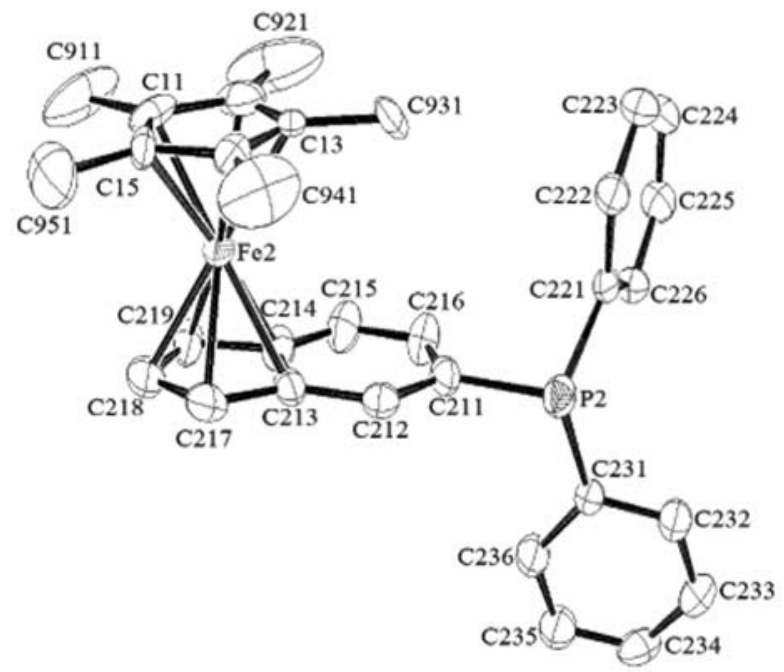

Fig. (1). ORTEP-3 drawing of the two major orientations of the molecules that constitute the asymmetric unit of 2a. Thermal ellipsoids are drawn at the $20 \%$ probability level. Selected bond distances and angles: Fe1-C1, 2.039(12)

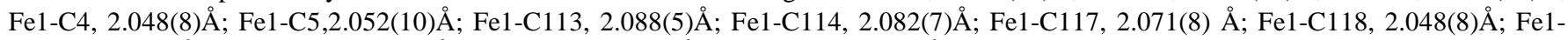

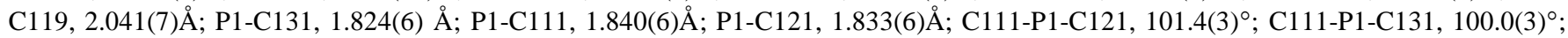

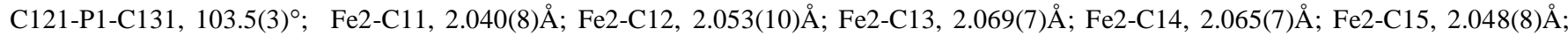

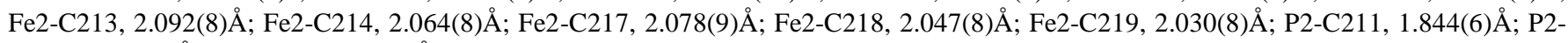

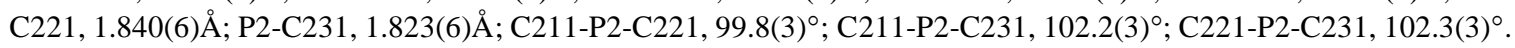


<smiles>CC(=O)O[C@H](/C=C/c1ccccc1)c1ccccc1</smiles><smiles>COC(=O)CC(=O)OC</smiles><smiles>COC(=O)C(C(=O)OC)C(/C=C/c1ccccc1)c1ccccc1</smiles>

\section{Equation 1.}

tween planes is $5.36^{\circ}$ and $4.80^{\circ}$ for molecules $\mathrm{Fe} 1$ and $\mathrm{Fe} 2$, respectively, see Fig. 1). In order to avoid the steric hindrance from the $\mathrm{Cp}^{*}$ and the 5-membered ring of indene, one phenyl group attached to the phosphorus atom points towards the exo face of the indenyl ring and the other one adopts a position that is opposite to the 5-membered ring of the indenyl moiety. As a result of such an orientation of the two phenyl groups, the lone pair on the phosphorus atom is directed towards the endo face of the indenyl plane. These structural features were also observed for 1a reported previously [3b]. The major structural difference between $\mathbf{2 a}$ and 1a is the steric hindrance around the phosphorus atom as indicated by their different ligand cone angles [5] roughly estimated here on the basis of the sum of the angles between the ipso carbon atoms bonded to phosphorus atom, which are $304.9^{\circ}$ and $304.3^{\circ}$ for the two molecules that represent $\mathbf{2 a}$ and $306.8^{\circ}$ for 1a. More importantly, the bulky $\mathrm{Cp}^{*}$ in $\mathbf{2 a}$ is further away from the phosphorus atom than that in 1a; and the lone pair of the phosphorus atom, to which the catalytic transition metal center is attached, in $\mathbf{1 a}$ is almost covered by a methyl group of the $\mathrm{Cp}^{*}$ [3b] while that in $\mathbf{2 a}$ is further away from $\mathrm{Cp}^{*}$ (Fig. 1). Therefore, 2a is a less hindered ligand than 1a; and one could infer that $\mathbf{2} \mathbf{b}$-d are also less hindered ligands than the corresponding $\mathbf{1 b - d .}$

Phosphine-transition metal complexes containing carbonyls such as $\mathrm{L}-\mathrm{Mo}(\mathrm{CO})_{5}$ and $\mathrm{L}-\mathrm{Ni}(\mathrm{CO})_{3}$ have been used for determination of electron donor-acceptor properties of phosphine ligands $[5 \mathrm{a}, 6]$; the frequency of $\mathrm{A}_{1}{ }^{2}$ band in the IR spectra of $\mathrm{L}-\mathrm{Mo}(\mathrm{CO})_{5}$ complexes correlates well with such properties [6b-d]. In order to analyze the electronic effects of the ligands on allylic alkylation and Suzuki coupling reactions, complexes 1a-Mo $(\mathrm{CO})_{5}, \mathbf{1 b}-\mathrm{Mo}(\mathrm{CO})_{5}, \mathbf{1 d}-\mathrm{Mo}(\mathrm{CO})_{5}$, $\mathbf{2 a - M o}(\mathrm{CO})_{5}, \mathbf{2 b}-\mathrm{Mo}(\mathrm{CO})_{5}, \mathbf{2 d}-\mathrm{Mo}(\mathrm{CO})_{5}$ and the known
$\mathrm{Ph}_{3} \mathrm{P}-\mathrm{Mo}(\mathrm{CO})_{5}$ were prepared according to the procedure reported by Lammertsma and co-workers by oxidative removal of a $\mathrm{CO}$ from $\mathrm{Mo}(\mathrm{CO})_{6}$ followed by in situ complexation with the phosphine ligands [7]. These complexes were also fully characterized with ${ }^{1} \mathrm{H},{ }^{13} \mathrm{C}$ and ${ }^{31} \mathrm{P}$ NMR and HRMS; their IR spectra were recorded and $\mathrm{A}_{1}{ }^{2}$ IR frequencies of them were identified. On the basis of the lower $A_{1}^{2}$ IR frequencies for all of the benzoferrocenyl phosphine ligands (including 1 and 2) compared to that for $\mathrm{PPh}_{3}$, we conclude that these ligands are stronger electron donors than $\mathrm{PPh}_{3}$. From these data, we also conclude that $\mathbf{2 a}$ has better electron donation ability than $\mathbf{1 a}$, and $\mathbf{2} \mathbf{b}, \mathbf{d}$ have similar electron donation capability as $\mathbf{1 b}, \mathbf{d}$.

The new ligands (2a-e) were applied to the palladiumcatalyzed allylic alkylation reaction between allyl acetate $\mathbf{5}$ and dimethyl malonate (6) (Eq. (1)). The catalysts were generated in situ by stirring $\left[\mathrm{Pd}\left(\mathrm{C}_{3} \mathrm{H}_{5}\right) \mathrm{Cl}\right]_{2}$ and a ligand in $\mathrm{CH}_{2} \mathrm{Cl}_{2}$ at $\mathrm{rt}$ for $1 \mathrm{~h}$. Under previously established allylic alkylation reaction conditions using $\mathrm{BSA}[\mathrm{N}, \mathrm{O}$-bis (trimethylsilyl)acetamine] and KOAc as base with an $\mathrm{L} / \mathrm{Pd}$ ratio of 2.5/1.0 [3b], when ligands $\mathbf{2 a}, \mathbf{b}$ were used, quantitative conversions were achieved within $15 \mathrm{~min}$ to generate the sole product 7 as indicated by GC-MS (entries 1 and 2, Table 1). Ligand 2c was also highly active under these conditions for the reaction; quantitative conversion was achieved within 45 min (entry 3). The bulkier 2d,e showed less activity, it took $44 \mathrm{~h}$ for the reaction to reach completion (entries 4 and 5).

In our previous report, when 1a-d were applied to this reaction under similar conditions, $\mathbf{1 a}, \mathbf{b}$ showed high activity, and the bulkier 1c,d showed significantly less activity [3b]. Comparing the two sets of ligands, 2a-d are much more active than the corresponding 1a-d. The biggest difference is between $\mathbf{2 c , d}$ and $\mathbf{1 c}, \mathbf{d}$, the latter gave much less conversions

Table 1. Application of Ligands 2a-e and 1d in Allylic Alkylation Reactions

\begin{tabular}{|c|c|c|c|c|c|c|c|}
\hline Entry & Ligand & Substrate/Pd & Substrates & Conditions & Temperature & Time (h) & Conversion $^{a}$ \\
\hline 1 & $2 a$ & $100 / 4$ & 5,6 & A & $\mathrm{rt}$ & 0.25 & $100 \%$ \\
\hline 3 & $2 \mathrm{c}$ & $100 / 4$ & 5,6 & A & $\mathrm{rt}$ & 0.75 & $100 \%$ \\
\hline 4 & 2d & $100 / 4$ & 5,6 & A & $\mathrm{rt}$ & 44 & $100 \%$ \\
\hline 6 & $2 a$ & $1,000 / 1$ & 8,6 & B & $\mathrm{rt}$ & 6 & $96 \%$ \\
\hline 7 & $2 a$ & $10,000 / 1$ & 8,6 & $\mathrm{~B}$ & $\mathrm{rt}$ & 72 & $85 \%$ \\
\hline 8 & 1d & $100 / 4$ & 5,6 & A & $40{ }^{\circ} \mathrm{C}$ & 4 & $100 \%$ \\
\hline
\end{tabular}

Conditions A: 51 eq; 63 eq; ligand 0.05 eq; $\left[\mathrm{Pd}\left(\mathrm{C}_{3} \mathrm{H}_{5}\right) \mathrm{Cl}\right]_{2} 0.02$ eq; BSA 3 eq; KOAc 0.1 eq; $\mathrm{CH}_{2} \mathrm{Cl}_{2}$.

Conditions B: 81 eq; 62 eq; $2 \mathrm{a} /\left[\mathrm{Pd}\left(\mathrm{C}_{3} \mathrm{H}_{5}\right) \mathrm{Cl}\right]_{2} 2.5 / 1 ; \mathrm{NaH} 2$ eq; THF.

${ }^{a}$ Determined by GC. In all cases, only mono-allylated product ( 7 or $\mathbf{9}$ ) was detected by GC-MS 


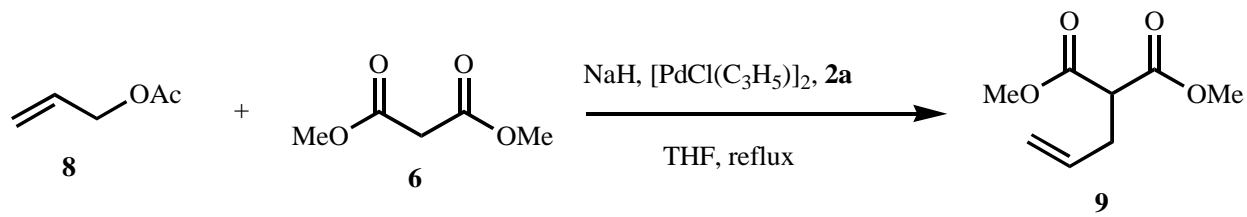

\section{Equation 2.}

than the former under similar conditions. Because $\mathbf{2 a}, \mathbf{b}$ are most active among 1a-d and 2a-e, and the phosphorus atom in $\mathbf{2 a}$ is less sensitive to oxidation than that in $\mathbf{2} \mathbf{b}$, we chose 2a to challenge the activity of ligands 2a-e in allylic alkylation by lowering the catalyst loading to $0.1 \%$. Under similar conditions (Conditions B, Table 1), the reaction reached $96 \%$ conversion within $6 \mathrm{~h}$ (entry 6 , Table $\mathbf{1}$ ). When catalyst loading was further lowered to $0.01 \%, 72 \mathrm{~h}$ were needed to achieve $85 \%$ conversion (entry 7 ); but despite the long reaction time, the reaction was still very clean as indicated by GC-MS. In 2001, Santelli's group reported the catalytic activity of several common phosphine ligands including $\mathrm{Ph}_{3} \mathrm{P}$, 1,2-bis(diphenylphosphino)ethane (dppe), 1,4bis(diphenylphosphino)butane (dppb) and cis,cis,cis-1,2,3,4tetrakis(diphenylphosphinomethyl)cyclopentane (tedicyp) in palladium-catalyzed allylic alkylation between allyl acetate and sodium dimethyl malonate [8]. They found that the monodentate $\mathrm{Ph}_{3} \mathrm{P}$ was virtually inactive (1\% conversion) when the catalyst loading was $0.01 \%$; dppe and dppb showed higher activity at this catalyst loading, but the conversions were still low (50\% and $49 \%$, respectively). Our ligand $2 \mathbf{a}$, which is monodentate, showed higher activity than these ligands. However, compared with the tetradentate tedicyp, which showed $100 \%$ conversion in $3 \mathrm{~h}$ with $0.01 \%$ catalyst loading, 2a is less active.

The activity of these ligands in the Suzuki coupling of chlorobenzene with phenylboronic acid was also assessed (Eq. (2)). Under conditions used previously with 1a-d as ligands [3a], 2a-e were found to be much less active. As shown in Table $\mathbf{2}$, when the less bulky $\mathbf{2 a}, \mathbf{b}$ were used, there were no conversion in $24 \mathrm{~h}$ (entries 1 and 2); the bulkier 2c-e showed some activity, but the conversions were low (entries 3-5). These results are in sharp contrast to those obtained using 1a-d as ligands; among them, 1c,d showed very high activity for this reaction under the same conditions [3a].

Locating the phosphorus atom on the 5-position as opposed to 4-position of benzoferrocenyl ligands significantly improved their activity in allylic alkylation reaction. The higher activity of $\mathbf{2 a - d}$ in allylic alkylation compared to that of the corresponding 1a-d can be attributed to the reduced steric hindrance around the phosphorus atom, which allows substrates to access the catalytic center more easily; and this trend of activity was also observed within the two series of ligands. Because $\mathrm{PPh}_{3}$ is less hindered than all these derived ligands, but much less active than $\mathbf{2 a}$, the electronic effect of the phosphines must also influence their activity. As shown in Table 3 , the lower $\mathrm{A}_{1}{ }^{2}$ IR frequencies of the complexes between the ligands and $\mathrm{Mo}(\mathrm{CO})_{5}$ compared with that of $\mathrm{Ph}_{3} \mathrm{P}-\mathrm{Mo}(\mathrm{CO})_{5}$ indicate that the benzoferrocenyl phosphines are better electron donor ligands than $\mathrm{PPh}_{3}$. Under the present allylic alkylation reaction conditions, the ionization of allyl acetates should be the rate limiting step, and therefore 2a is more active than $\mathrm{PPh}_{3}$. Because 2a is a better donor ligand than 1a (Table 3), this electronic effect may also contribute to the higher activity of $\mathbf{2 a}$ compared with $1 \mathbf{a}$ in addition to any steric effects. The electron donor abilities of $\mathbf{1 b}$ and $\mathbf{2 b}$, and those of $\mathbf{1 d}$ and $\mathbf{2 d}$ are very close; therefore the difference between their activities can be attributed to the different steric environment around their phosphorus atoms.

Having the phosphorus atom on the 5-position as opposed to the 4-position on the benzoferrocenyl ligands significantly lowered their activity for the Suzuki coupling of aryl chlorides with boronic acids. In these reactions, the rate limiting step is the oxidative addition in which $\operatorname{Pd}(0)$ inserts into the $\mathrm{C}-\mathrm{Cl}$ bond. Because of the relatively less reactive nature of $\mathrm{C}-\mathrm{Cl}$ bonds, this step requires electron-rich and bulky phosphine ligands to form the mono-coordinated $12 \mathrm{e}$ $\operatorname{LPd}(0)$ complex [2]. The data in Table $\mathbf{3}$ show that $\mathbf{2 a}$ is more electron rich than $\mathbf{1 a}$, and $\mathbf{2 b}, \mathbf{d}$ have similar electron donating capability as $\mathbf{1 b}, \mathbf{d}$; therefore the reduced activity of 2a-e compared with 1a-d is caused by the reduced steric hindrance around the phosphorus atom, which reduces the likelihood of forming mono-coordinated $\operatorname{LPd}(0)$ complexes.

Table 2. Application of Ligands 2a-e in Suzuki Coupling

$\mathrm{Ph}-\mathrm{Cl}+\mathrm{Ph}-\mathrm{B}(\mathrm{OH})_{2} \longrightarrow \mathrm{Ph}-\mathrm{Ph}$

\begin{tabular}{|c|c|c|c|}
\hline Entry & Ligand & Time (h) & Conversion $^{\text {a }}$ \\
\hline \hline 1 & $\mathbf{2 a}$ & 24 & $0 \%$ \\
\hline 2 & $\mathbf{2 b}$ & 24 & $0 \%$ \\
\hline 3 & $\mathbf{2 c}$ & 2 & $15 \%$ \\
\hline 4 & $\mathbf{2 d}$ & 24 & $11 \%$ \\
\hline 5 & $\mathbf{2 e}$ & 24 & $6 \%$ \\
\hline
\end{tabular}

Conditions: $\mathrm{Ph}-\mathrm{Cl} 1$ eq; $\mathrm{Ph}-\mathrm{B}(\mathrm{OH})_{2}$ leq; ligand 0.036 eq; $\mathrm{Pd}_{2}(\mathrm{dba})_{3} 0.015$ eq; $\mathrm{Cs}_{2} \mathrm{CO}_{3} 2$ eq; 1,4-dioxane; reflux.

${ }^{a}$ Determined by GC. 
Table 3. $\quad \mathrm{A}_{1}{ }^{2}$ IR Frequency Data for L-Mo(CO $)_{5}$ Complexes

\begin{tabular}{|c|c|}
\hline Complex & Frequency $\left(\mathbf{c m}^{-\mathbf{1}}\right)$ \\
\hline \hline $\mathrm{Ph}_{3} \mathrm{P}-\mathrm{Mo}(\mathrm{CO})_{5}$ & 2073 \\
\hline 1a-Mo(CO) & \\
\hline 1b-Mo(CO $)_{5}$ & 2071 \\
\hline 1d-Mo(CO $)_{5}$ & 2070 \\
\hline 2a-Mo(CO $)_{5}$ & 2066 \\
\hline 2b-Mo(CO $)_{5}$ & 2067 \\
\hline 2d-Mo(CO $)_{5}$ & 2069 \\
\hline
\end{tabular}

In allylic alkylation reactions, the $14 \mathrm{e}_{2} \mathrm{Pd}(0)$ complex is believed to be responsible for the ionization of allyl acetates, which is the rate-limiting step of the reaction under the conditions we used [3a]; the rate of this ionization process decreases with increasing steric hindrance of the ligand. It is interesting to note that the seemingly more hindered $\mathrm{L}_{2} \mathrm{Pd}$ of $\mathbf{1 a}, \mathbf{b}$ and $\mathbf{2 a}, \mathbf{b}$ could catalyze allylic alkylation reaction with high efficiency but the relatively less hindered LPd of $\mathbf{1 c , d}$ and $\mathbf{2 d}$ showed much lower efficiency for the same reaction, while the latter showed high efficiency for Suzuki coupling of aryl chlorides with arylboronic acids [3a]. One possible explanation is that mono-coordinated LPd does not exist or exist at very low concentration and $\mathrm{L}_{2} \mathrm{Pd}$ predominates at $\mathrm{rt}$ even with the highly hindered ligands such as $\mathbf{1 c}, \mathbf{d}$ and $\mathbf{2 d}$; LPd can only exist with useful amount at elevated temperature when the ligand is bulky. As a result, ligands such as 1c,d and 2d showed low activity for allylic alkylation, which was performed at rt; but showed high activity in Suzuki coupling of aryl chlorides, which was performed at elevated temperature. If this is true, at elevated temperature, highly hindered ligands such as $\mathbf{1 c}, \mathbf{d}$ and $\mathbf{2 d}$ should also show high activity for allylic alkylation. To test this hypothesis, $\mathbf{1 d}$ was used as the ligand for allylic alkylation reaction under conditions A but at $40{ }^{\circ} \mathrm{C}$ (instead of rt), and indeed high activity was displayed; within $4 \mathrm{~h}$ quantitative conversion was observed (entry 8 , Table 1). This observation shows that $\mathrm{L}_{2} \mathrm{Pd}$ complexes of $\mathbf{1 c}, \mathbf{d}$ and $\mathbf{2 d}$ are not active for allylic alkylation but LPd complexes of the same ligands may be highly active for this reaction.

\section{CONCLUSIONS}

Five novel benzoferrocenyl phosphine ligands with the phosphorus atom attached to the 5-position (2a-e) were prepared and fully characterized. Like their analogs with the phosphorus atom attached to the 4-position (1a-d), these ligands are chemically stable and are suitable for applications in catalysis. IR analysis of the complexes of these ligands (1 and 2) with $\operatorname{Mo}(\mathrm{CO})_{5}$ indicates that 2a is a stronger electron donor than $\mathbf{1 a}$, and $\mathbf{2 b}, \mathbf{d}$ have similar electron donating capability as $\mathbf{1 b}, \mathbf{d}$. With these electronic characteristics and the reduced steric hindrance around their phosphorus atom, 2a-d have higher activity in allylic alkylation and lower activity in Suzuki coupling of aryl chlorides than the corresponding 1a-d. Preparation of multidentate version of benzoferrocene ligands in enantiopure form and using them to solve problems in asymmetric catalysis are in progress; results of these investigations will be reported in the near future.

\section{EXPERIMENTAL SECTION}

\section{General Information}

All reactions were performed under a nitrogen atmosphere using standard Schlenk techniques. Reagents and solvents available from commercial sources were used as received unless otherwise noted. THF, $\mathrm{Et}_{2} \mathrm{O}$ and toluene were distilled from $\mathrm{Na}$ /benzophenone ketyl. $\mathrm{CH}_{2} \mathrm{Cl}_{2}$ and acetonitrile were distilled over $\mathrm{CaH}_{2}$. Thin layer chromatography (TLC) was performed using Sigma-Aldrich TLC plates, silica gel $60 \mathrm{~F}-254$ over glass support, $0.25 \mu \mathrm{m}$ thickness. Flash column chromatography was performed using Selecto Scientific silica gel, particle size $32-63 \mu \mathrm{m}$ in diameter. ${ }^{1} \mathrm{H},{ }^{13} \mathrm{C}$ and ${ }^{31} \mathrm{P}$ NMR were measured on a Varian Unity spectrometer at $400 \mathrm{MHz}$; chemical shifts $(\delta)$ were reported to residue $\mathrm{CHCl}_{3}\left(\delta=7.27 \mathrm{ppm}\right.$ for ${ }^{1} \mathrm{H}$ and $77.23 \mathrm{ppm}$ for $\left.{ }^{13} \mathrm{C}\right)$ and $\mathrm{C}_{6} \mathrm{D}_{5} \mathrm{H}\left(\delta=7.34 \mathrm{ppm}\right.$ for ${ }^{1} \mathrm{H}$ and $128.36 \mathrm{ppm}$ for $\left.{ }^{13} \mathrm{C}\right)$, and to the external standard $\mathrm{H}_{3} \mathrm{PO}_{4}\left(\delta=0\right.$ ppm for $\left.{ }^{31} \mathrm{P}\right)$. GC-MS were measured on GCMS-QP5050A, Shimadzu; column, DB-5MS, $0.25 \mu \mathrm{m}$ thickness, $0.25 \mathrm{~mm}$ diameter, $25 \mathrm{~m}$ length; MS, positive EI. Melting points were determined using a MEL-TEMP ${ }^{\circledR}$ melting point apparatus and are uncorrected. IR spectra were recorded in a solution of $\mathrm{CHCl}_{3}$ on a PerkinElmer "Spectrum one FT-IR Spectrometer".

\section{5-Bromoindenyl-pentamethylcyclopentadienyliron (4)}

6-Bromo-1 $(H)$-indene $(\mathbf{3}, 3.0 \mathrm{~g}, 15.4 \mathrm{mmol})$ in THF $(150$ $\mathrm{mL})$ was cooled to $-78{ }^{\circ} \mathrm{C}, n$-BuLi $(2.0 \mathrm{M}$ in pentane, 7.7 $\mathrm{mL}, 15.4 \mathrm{mmol}$ ) was added via syringe along the wall of flask in a dropwise manner. After addition, the solution was warmed to rt slowly. Pentamethylcyclopentadiene $\left(\mathrm{Cp}^{*}-\mathrm{H}\right.$, $2.2 \mathrm{~mL}, 15.4 \mathrm{mmol})$ in THF $(100 \mathrm{~mL})$ in another roundbottomed flask was treated with $n-\mathrm{BuLi}(2.0 \mathrm{M}$ in pentane, $7.7 \mathrm{~mL}, 15.4 \mathrm{mmol}$ ) at $\mathrm{rt}$ giving a white suspension. This white suspension was added via cannula to a suspension of anhydrous $\mathrm{FeCl}_{2}(1.97 \mathrm{~g}, 15.4 \mathrm{mmol})$ in THF $(100 \mathrm{~mL})$ with vigorous stirring. After stirring at $\mathrm{rt}$ for $1 \mathrm{~h}$, the solution of lithiated $\mathbf{3}$ was added dropwise via cannula, and the resulting deep red solution was stirred at rt. After $3 \mathrm{~h}$, TLC $\left(\mathrm{SiO}_{2}\right.$, hexanes) indicated quantitative conversion. THF was removed under reduced pressure on a rotary evaporator. The deep red residue was partitioned between $10 \% \mathrm{~K}_{2} \mathrm{CO}_{3}(100$ $\mathrm{mL})$ and hexanes $(200 \mathrm{~mL})$, and the organic layer was further washed sequentially with $10 \% \mathrm{~K}_{2} \mathrm{CO}_{3}(25 \mathrm{~mL})$ and water $(25 \mathrm{~mL})$. After drying over anhydrous $\mathrm{Na}_{2} \mathrm{SO}_{4}$, the deep red solution was concentrated to about $15 \mathrm{~mL}$. Cooling the solution to $-20{ }^{\circ} \mathrm{C}$ gave pure product $\mathbf{4}$ as deep red crystals (3.61 g, 61\%): $R_{f}=0.75$ (hexanes); $\mathrm{mp} 82-84{ }^{\circ} \mathrm{C} ;{ }^{1} \mathrm{H}$ NMR $\left(\mathrm{C}_{6} \mathrm{D}_{6}\right) \delta 7.10$ (brs, $1 \mathrm{H}, \mathrm{H}-4, \mathrm{H}-6$ or H-7), 6.93 (brs, $1 \mathrm{H}, \mathrm{H}-4$, H-6 or H-7), 6.89 (brs, 1H, H-4, H-6 or H-7), 4.02 (brs, 1H, $\mathrm{H}-1, \mathrm{H}-2$ or H-3), 3.99 (brs, 1H, H-1, H-2 or H-3), 3.52 (brs, $1 \mathrm{H}, \mathrm{H}-1, \mathrm{H}-2$ or $\mathrm{H}-3), 1.46\left(\mathrm{~s}, 15 \mathrm{H}, \mathrm{Cp}^{*}\right) ;{ }^{13} \mathrm{C}$ NMR $\left(\mathrm{C}_{6} \mathrm{D}_{6}\right) \delta$ 130.1 (C-4, C-6 or C-7), 129.1 (C-4, C-6 or C-7), 126.0 (C4, C-6 or C-7), 114.6 (C-5), 90.1 (C-3' or C-7'), 86.4 (C-3' or C-7'), 78.2 (C-1, C-2, C-3 or Cp*), 76.6 (C-1, C-2, C-3 or Cp*), 66.1 (C-1, C-2, C-3 or Cp*), 65.8 (C-1, C-2, C-3 or $\left.\mathrm{Cp}^{*}\right), 10.1$ (Cp*-Me); EI-MS calcd. for $\mathrm{C}_{19} \mathrm{H}_{21} \mathrm{BrFe}(\mathrm{m} / \mathrm{z})$ $\left[\mathrm{M}^{+}\right]$384, found 384; FAB-HRMS (NBA) calcd. for $\mathrm{C}_{19} \mathrm{H}_{21} \mathrm{BrFe}(\mathrm{m} / \mathrm{z})\left[\mathrm{M}^{+}\right]$384.0176; found 384.0177. Anal. 
calcd. for $\mathrm{C}_{19} \mathrm{H}_{21} \mathrm{BrFe} \mathrm{C}$ 58.26, H 5.50; found C 59.05, H 5.38 .

\section{5-(Diphenylphosphino)indenyl-pentamethylcyclopentadien- yliron (2a)}

The deep red solution of $4(1.0 \mathrm{~g}, 2.6 \mathrm{mmol})$ in $\mathrm{Et}_{2} \mathrm{O}$ (50 $\mathrm{mL})$ in a round-bottomed flask was cooled to $-78{ }^{\circ} \mathrm{C}$. To this solution was added $t$-BuLi $(1.7 \mathrm{M}$ in pentane, $3.3 \mathrm{~mL}, 5.7$ mmol) slowly via syringe and the mixture was stirred at the same temperature for $30 \mathrm{~min}$. $P$-Chlorodiphenylphosphine $(1.1 \mathrm{~mL}, 5.7 \mathrm{mmol})$ was next added dropwise via syringe. After stirring at $-78{ }^{\circ} \mathrm{C}$ for $2 \mathrm{~h}$, the reaction was quenched with water, and the mixture partitioned between $10 \% \mathrm{~K}_{2} \mathrm{CO}_{3}$ $(25 \mathrm{~mL})$ and hexanes $(50 \mathrm{~mL})$. The isolated organic layer further washed sequentially with $10 \% \mathrm{~K}_{2} \mathrm{CO}_{3}(25 \mathrm{~mL})$ and water $(25 \mathrm{~mL})$. After drying over anhydrous $\mathrm{Na}_{2} \mathrm{SO}_{4}$, the solution was concentrated to dryness. Flash column chromatography $\left(\mathrm{SiO}_{2}\right.$, pretreated with $5 \% \mathrm{Et}_{3} \mathrm{~N}$ in hexanes; hexanes) gave product 2a as deep purple crystals $(0.87 \mathrm{~g}, 68 \%)$ : $R_{f}=0.23$ (hexanes); mp 126-128 ${ }^{\circ} \mathrm{C} ;{ }^{1} \mathrm{H}$ NMR $\left(\mathrm{C}_{6} \mathrm{D}_{6}\right) \delta 7.59-$ $7.55(\mathrm{~m}, 1 \mathrm{H}, \mathrm{Ph}), 7.51-7.46(\mathrm{~m}, 1 \mathrm{H}, \mathrm{Ph}), 7.15-6.95(\mathrm{~m}, 11 \mathrm{H}$, $\mathrm{Ph}), 4.11(\mathrm{dt}, 1 \mathrm{H}, J=2.4,0.8 \mathrm{~Hz}, \mathrm{H}-1$ or $\mathrm{H}-3), 4.05(\mathrm{dt}, 1 \mathrm{H}$, $J=2.4,0.8 \mathrm{~Hz}, \mathrm{H}-1$, or $\mathrm{H}-3), 3.60$ (t, $1 \mathrm{H}, J=2.4 \mathrm{~Hz}, \mathrm{H}-2)$, $1.47(\mathrm{~s}, 15 \mathrm{H}, \mathrm{Cp} *) ;{ }^{13} \mathrm{C}$ NMR $\left(\mathrm{C}_{6} \mathrm{D}_{6}\right) \delta 138.8\left(\mathrm{~d}, J_{C P}=48.4\right.$ $\mathrm{Hz}, \mathrm{Ph}), 136.8\left(\mathrm{~d}, J_{C P}=115.2 \mathrm{~Hz}, \mathrm{Ph}\right), 134.4\left(\mathrm{~d}, J_{C P}=78.8\right.$ $\mathrm{Hz}, \mathrm{Ph}), 133.7\left(\mathrm{~d}, J_{C P}=72.8 \mathrm{~Hz}, \mathrm{Ph}\right), 130.6\left(\mathrm{~d}, J_{C P}=42.4\right.$ $\mathrm{Hz}, \mathrm{Ph}), 128.6\left(\mathrm{~d}, J_{C P}=42.4 \mathrm{~Hz}, \mathrm{Ph}\right), 128.4\left(\mathrm{~d}, J_{C P}=60.8\right.$ $\mathrm{Hz}, \mathrm{Ph}), 126.7\left(\mathrm{~d}, J_{C P}=60.8 \mathrm{~Hz}, \mathrm{Ph}\right), 88.36\left(\mathrm{~d}, J_{C P}=42.8\right.$ Hz, C-3'), 88.4 (C-7'), 78.1 (C-1 or C-3), 76.7 (C-1 or C-3), $66.4\left(\mathrm{C}-2\right.$ or $\left.\mathrm{Cp}^{*}\right), 66.3\left(\mathrm{C}-2\right.$ or $\left.\mathrm{Cp}^{*}\right), 10.2\left(\mathrm{Cp}^{*}-\mathrm{Me}\right) ;{ }^{31} \mathrm{P}$ NMR $\left(\mathrm{C}_{6} \mathrm{D}_{6}\right) \delta$-2.28; EI-MS calcd. for $\mathrm{C}_{31} \mathrm{H}_{31} \mathrm{FeP}(\mathrm{m} / z)\left[\mathrm{M}^{+}\right]$ 490, found 490; FAB-HRMS (NBA) calcd. for $\mathrm{C}_{31} \mathrm{H}_{31} \mathrm{FeP}$ $(\mathrm{m} / \mathrm{z})\left[\mathrm{M}^{+}\right]$490.1513; found 490.1516.

\section{5-(Diethylphosphino)indenyl-pentamethylcyclopentadieny- liron (2b)}

Following the procedure for the preparation of $\mathbf{2 a}$, compound $2 \mathbf{b}$ was synthesized in $60 \%$ yield as a deep red sticky solid: $R_{f}=0.24$ (hexanes); ${ }^{1} \mathrm{H}$ NMR $\left(\mathrm{C}_{6} \mathrm{D}_{6}\right) \delta 7.67(\mathrm{~d}, 1 \mathrm{H}, J=$ $10 \mathrm{~Hz}, \mathrm{Ph}), 7.16(\mathrm{~d}, 1 \mathrm{H}, J=8.8 \mathrm{~Hz}, \mathrm{Ph}), 7.01(\mathrm{dd}, 1 \mathrm{H}, J=$ $8.4,3.6 \mathrm{~Hz}, \mathrm{Ph}), 4.15$ (t, $2 \mathrm{H}, J=2.4 \mathrm{~Hz}, \mathrm{H}-1$ and $\mathrm{H}-3), 3.61$ $(\mathrm{t}, 1 \mathrm{H}, J=2.4 \mathrm{~Hz}, \mathrm{H}-2), 1.68-1.52\left(\mathrm{~m}, 4 \mathrm{H}, \mathrm{PCH}_{2}\right), 1.52(\mathrm{~s}$, $\left.15 \mathrm{H}, \mathrm{Cp}^{*}-\mathrm{Me}\right), 1.56-0.96(\mathrm{~m}, 6 \mathrm{H}, \mathrm{Me}) ;{ }^{13} \mathrm{C}$ NMR $\left(\mathrm{C}_{6} \mathrm{D}_{6}\right) \delta$ $135.2\left(\mathrm{~d}, J_{C P}=127.6 \mathrm{~Hz}, \mathrm{Ph}\right), 132.2\left(\mathrm{~d}, J_{C P}=66.8 \mathrm{~Hz}, \mathrm{C}-5\right)$, $127.4\left(\mathrm{~d}, J_{C P}=18.0 \mathrm{~Hz}, \mathrm{Ph}\right), 124.1\left(\mathrm{~d}, J_{C P}=42.4 \mathrm{~Hz}, \mathrm{Ph}\right)$, 88.6 (C-7'), 88.5 (d, $\left.J_{C P}=42.4 \mathrm{~Hz}, \mathrm{C}-3^{\prime}\right), 77.8(\mathrm{C}-2$ or C-3), $76.4(\mathrm{C}-2$ or $\mathrm{C}-3), 66.2\left(\mathrm{C}-2\right.$ or $\left.\mathrm{Cp}^{*}\right), 66.1\left(\mathrm{C}-2\right.$ or $\left.\mathrm{Cp}^{*}\right)$, $20.9\left(\mathrm{~d}, J_{C P}=79.2 \mathrm{~Hz}, \mathrm{PCH}_{2}\right), 20.7\left(\mathrm{~d}, J_{C P}=78.8 \mathrm{~Hz}\right.$, $\left.\mathrm{PCH}_{2}\right), 10.4\left(\mathrm{~d}, J_{C P}=42.4 \mathrm{~Hz}, \mathrm{Me} \times 2\right), 10.2(\mathrm{Cp} *-\mathrm{Me}) ;{ }^{31} \mathrm{P}$ NMR $\left(\mathrm{C}_{6} \mathrm{D}_{6}\right) \delta$-13.59; EI-MS calcd. for $\mathrm{C}_{23} \mathrm{H}_{31} \mathrm{FeP}(\mathrm{m} / \mathrm{z})$ $\left[\mathrm{M}^{+}\right]$394, found 394; FAB-HRMS (NBA) calcd. for $\mathrm{C}_{23} \mathrm{H}_{31} \mathrm{FeP}(\mathrm{m} / \mathrm{z})\left[\mathrm{M}^{+}\right]$394.1513; found 394.1513.

\section{5-(Diisopropylphosphino)indenyl-pentamethylcyclopentad- ienyliron (2c)}

Following the procedure for the preparation of $\mathbf{2 a}$, compound $2 \mathbf{c}$ was synthesized in 65\% yield as a deep red sticky solid: $R_{f}=0.17$ (hexanes); ${ }^{1} \mathrm{H}$ NMR $\left(\mathrm{C}_{6} \mathrm{D}_{6}\right) \delta 7.68(\mathrm{~d}, 1 \mathrm{H}, J=$ $11.2 \mathrm{~Hz}, \mathrm{Ph}), 7.14(\mathrm{~d}, 1 \mathrm{H}, J=8.8 \mathrm{~Hz}, \mathrm{Ph}), 6.98$ (d, $J=8.4$ $\mathrm{Hz}, \mathrm{Ph}), 4.17$ (s, 1H, H-1 or H-3), $4.15(\mathrm{~d}, 1 \mathrm{H}, J=2.4 \mathrm{~Hz}, \mathrm{H}-$ 1 or H-3), 3.58 (t, $1 \mathrm{H}, J=2.4 \mathrm{~Hz}, \mathrm{H}-2), 2.14-2.02(\mathrm{~m}, 1 \mathrm{H}$, $\mathrm{PCH}), 1.94-1.84(\mathrm{~m}, 1 \mathrm{H}, \mathrm{PCH}), 1.55\left(\mathrm{~s}, 15 \mathrm{H}, \mathrm{Cp}^{*}-\mathrm{Me}\right)$,
1.20-0.88 (m, 12H, Me); ${ }^{13} \mathrm{C}$ NMR $\left(\mathrm{C}_{6} \mathrm{D}_{6}\right) \delta 137.9\left(\mathrm{~d}, J_{C P}=\right.$ $145.6 \mathrm{~Hz}, \mathrm{Ph}), 129.0\left(\mathrm{~d}, J_{C P}=79.2 \mathrm{~Hz}, \mathrm{C}-5\right), 126.5(\mathrm{Ph})$, $125.8(\mathrm{Ph}), 88.7\left(\mathrm{C}-3^{\prime}\right.$ and $\mathrm{C}-7$ '), $78.0(\mathrm{C}-1$ or C-3), $76.4(\mathrm{C}-$ 1 or C-3), $66.4\left(\mathrm{C}-2\right.$ or $\left.\mathrm{Cp}^{*}\right), 66.2\left(\mathrm{C}-2\right.$ or $\left.\mathrm{Cp}^{*}\right), 23.8$ (d, $J_{C P}$ $=54.4 \mathrm{~Hz}, \mathrm{PCH}), 22.8\left(\mathrm{~d}, J_{C P}=48.4 \mathrm{~Hz}, \mathrm{PCH}\right), 20.4\left(\mathrm{~d}, J_{C P}\right.$ $=72.8 \mathrm{~Hz}, \mathrm{Me}), 20.1\left(\mathrm{~d}, J_{C P}=30.4 \mathrm{~Hz}, \mathrm{Me}\right), 20.0(\mathrm{Me}), 18.8$ (Me), $10.4(\mathrm{Cp} *-\mathrm{Me}) ;{ }^{31} \mathrm{P}$ NMR $\left(\mathrm{C}_{6} \mathrm{D}_{6}\right) \delta 14.2$; EI-MS calcd. for $\mathrm{C}_{25} \mathrm{H}_{35} \mathrm{FeP}(\mathrm{m} / \mathrm{z})\left[\mathrm{M}^{+}\right]$422, found 422; FAB-HRMS (NBA) calcd. for $\mathrm{C}_{25} \mathrm{H}_{35} \mathrm{FeP}(\mathrm{m} / \mathrm{z})\left[\mathrm{M}^{+}\right]$422.1826; found 422.1829.

\section{5-(Dicyclohexylphosphino)indenyl-pentamethylcyclopen- tadienyliron (2d)}

Following the procedure for the preparation of $\mathbf{2 a}$, compound 2d was synthesized in $62 \%$ yield as a deep red solid: $R_{f}=0.25$ (hexanes); mp $116-118{ }^{\circ} \mathrm{C} ;{ }^{1} \mathrm{H}$ NMR $\left(\mathrm{CDCl}_{3}\right) \delta$ $7.31(\mathrm{dd}, 1 \mathrm{H}, J=11.6,0.8 \mathrm{~Hz}, \mathrm{Ph}), 7.27(\mathrm{~d}, 1 \mathrm{H}, J=8.4 \mathrm{~Hz}$, $\mathrm{Ph}$ ), 7.04 (ddd, $1 \mathrm{H}, J=8.80,3.2,1.2 \mathrm{~Hz}, \mathrm{Ph}), 4.37$ (d, $1 \mathrm{H}, J$ $=2.8 \mathrm{~Hz}, \mathrm{H}-1$ or $\mathrm{H}-3), 4.34(\mathrm{~d}, 1 \mathrm{H}, J=2.4 \mathrm{~Hz}, \mathrm{H}-1$ or H-3), $3.80(\mathrm{t}, 1 \mathrm{H}, J=2.4 \mathrm{~Hz}, \mathrm{H}-2), 2.05-1.58[\mathrm{~m}, 10 \mathrm{H}$, $\left.\mathrm{PCH}\left(\mathrm{CH}_{2}\right)_{2}\right], 1.68$ (s, 15H, Cp*-Me), 1.39-0.98 [m, 12H, $\left.\left(\mathrm{CH}_{2}\right)_{3}\right] ;{ }^{13} \mathrm{C} \mathrm{NMR}\left(\mathrm{CDCl}_{3}\right) \delta 137.8\left(\mathrm{~d}, J_{C P}=146.0 \mathrm{~Hz}, \mathrm{Ph}\right)$, $128.5\left(\mathrm{~d}, J_{C P}=60.4 \mathrm{~Hz}, \mathrm{C}-5\right), 126.4\left(\mathrm{~d}, J_{C P}=42.4 \mathrm{~Hz}, \mathrm{Ph}\right)$, $126.2(\mathrm{Ph}), 88.6\left(\mathrm{~d}, J_{C P}=54.4 \mathrm{~Hz}, \mathrm{C}^{\prime} 3^{\prime}\right), 88.6\left(\mathrm{C}^{-7} 7^{\prime}\right), 78.4$ (C-1 or C-3), 76.4 (C-1 or C-3), 66.3 (C-2 or Cp*), 66.1 (C-2 or $\left.\mathrm{Cp}^{*}\right), 33.6\left(\mathrm{~d}, J_{C P}=48.8 \mathrm{~Hz}, \mathrm{PCH}\right), 32.5\left(\mathrm{~d}, J_{C P}=42.4\right.$ $\mathrm{Hz}, \mathrm{PCH}), 30.6\left(\mathrm{~d}, J_{C P}=66.4 \mathrm{~Hz}, \mathrm{CH}_{2}\right), 30.2\left(\mathrm{~d}, J_{C P}=66.8\right.$ $\left.\mathrm{Hz}, \mathrm{CH}_{2}\right), 30.0\left(\mathrm{~d}, J_{C P}=42.4 \mathrm{~Hz}, \mathrm{CH}_{2}\right), 29.1\left(\mathrm{~d}, J_{C P}=18.4\right.$ $\left.\mathrm{Hz}, \mathrm{CH}_{2}\right), 27.6\left(\mathrm{~d}, J_{C P}=54.8 \mathrm{~Hz}, \mathrm{CH}_{2}\right), 27.5\left(\mathrm{CH}_{2}\right), 27.3$ $\left(\mathrm{CH}_{2}\right), 27.3\left(\mathrm{~d}, J_{C P}=36.4 \mathrm{~Hz}, \mathrm{CH}_{2}\right), 26.7\left(\mathrm{CH}_{2}\right), 26.6\left(\mathrm{CH}_{2}\right)$, $10.6\left(\mathrm{Cp}^{*}-\mathrm{Me}\right) ;{ }^{31} \mathrm{P}$ NMR $\left(\mathrm{CDCl}_{3}\right) \delta 7.13$; EI-MS calcd. for $\mathrm{C}_{31} \mathrm{H}_{43} \mathrm{FeP}(\mathrm{m} / z)\left[\mathrm{M}^{+}\right]$502, found 502; FAB-HRMS (NBA) calcd. for $\mathrm{C}_{31} \mathrm{H}_{43} \mathrm{FeP}(\mathrm{m} / \mathrm{z})\left[\mathrm{M}^{+}\right]$502.2452; found 502.2449.

\section{5-(Dicyclopentylphosphino)indenyl-pentamethylcyclopent- adienyliron (2e)}

Following the procedure for the preparation of $\mathbf{2 a}$, compound $2 \mathrm{e}$ was synthesized in 58\% yield as a deep red sticky solid: $R_{f}=0.21$ (hexanes); ${ }^{1} \mathrm{H}$ NMR $\left(\mathrm{C}_{6} \mathrm{D}_{6}\right) \delta 7.72(\mathrm{~d}, 1 \mathrm{H}, J=$ $11.2 \mathrm{~Hz}, \mathrm{Ph}), 7.16(\mathrm{~d}, 1 \mathrm{H}, J=8.8 \mathrm{~Hz}, \mathrm{Ph}), 7.05(\mathrm{dd}, 1 \mathrm{H}, J=$ $8.8,3.2 \mathrm{~Hz}, \mathrm{Ph}), 4.18(\mathrm{~d}, 1 \mathrm{H}, J=1.6 \mathrm{~Hz}, \mathrm{H}-1$ or $\mathrm{H}-3), 4.14$ (d, $1 \mathrm{H}, J=2.4 \mathrm{~Hz}, \mathrm{H}-1$ or H-3), $3.58(\mathrm{t}, 1 \mathrm{H}, J=2.8 \mathrm{~Hz}, \mathrm{H}-$ 2), 2.26-2.16 (m, 1H, PCH), 2.04-1.94 (m, 1H, PCH), 1.91$1.22\left(\mathrm{~m}, 16 \mathrm{H}, \mathrm{CH}_{2}\right), 1.56\left(\mathrm{~s}, 15 \mathrm{H}, \mathrm{Cp}^{*}-\mathrm{Me}\right) ;{ }^{13} \mathrm{C} \mathrm{NMR}$ $\left(\mathrm{C}_{6} \mathrm{D}_{6}\right) \delta 136.8\left(\mathrm{~d}, J_{C P}=151.6 \mathrm{~Hz}, \mathrm{Ph}\right), 132.5\left(\mathrm{~d}, J_{C P}=66.8\right.$ $\mathrm{Hz}, \mathrm{C}-5), 126.8\left(\mathrm{~d}, J_{C P}=12.0 \mathrm{~Hz}, \mathrm{Ph}\right), 125.2\left(\mathrm{~d}, J_{C P}=18.4\right.$ $\mathrm{Hz}, \mathrm{Ph}), 88.6$ (C-7'), 88.5 (d, $J_{C P}=48.8 \mathrm{~Hz}, \mathrm{C}-3$ '), 77.9 (C-1 or C-3), 76.3 (C-1 or C-3), 66.4 (C-2 or Cp*), 66.1 (C-2 or $\left.\mathrm{Cp}^{*}\right), 38.2\left(\mathrm{~d}, J_{C P}=48.8 \mathrm{~Hz}, \mathrm{PCH}\right), 36.7\left(\mathrm{~d}, J_{C P}=48.8 \mathrm{~Hz}\right.$, PCH), $31.7\left(\mathrm{~d}, J_{C P}=12.0 \mathrm{~Hz}, \mathrm{CH}_{2}\right), 31.6\left(\mathrm{~d}, J_{C P}=48.8 \mathrm{~Hz}\right.$, $\left.\mathrm{CH}_{2}\right), 31.4\left(\mathrm{CH}_{2}\right), 31.1$ (d, $\left.J_{C P}=48.8 \mathrm{~Hz}, \mathrm{CH}_{2}\right), 27.0\left(\mathrm{~d}, J_{C P}\right.$ $\left.=24.0 \mathrm{~Hz}, \mathrm{CH}_{2}\right), 26.8\left(\mathrm{~d}, J_{C P}=30.4 \mathrm{~Hz}, \mathrm{CH}_{2}\right), 26.3\left(\mathrm{~d}, J_{C P}=\right.$ $\left.24.4 \mathrm{~Hz}, \mathrm{CH}_{2}\right), 25.9$ (d, $\left.J_{C P}=24.4 \mathrm{~Hz}, \mathrm{CH}_{2}\right), 10.5\left(\mathrm{Cp}^{*}-\mathrm{Me}\right)$; ${ }^{31} \mathrm{P}$ NMR $\left(\mathrm{C}_{6} \mathrm{D}_{6}\right) \delta 4.77$; EI-MS calcd. for $\mathrm{C}_{29} \mathrm{H}_{39} \mathrm{FeP}(\mathrm{m} / \mathrm{z})$ $\left[\mathrm{M}^{+}\right]$474, found 474; FAB-HRMS (NBA) calcd. for $\mathrm{C}_{29} \mathrm{H}_{39} \mathrm{FeP}(\mathrm{m} / \mathrm{z})\left[\mathrm{M}^{+}\right]$474.2139; found 474.2141.

\section{[5-(Diphenylphosphino)indenyl-pentamethylcyclopentad- ienyliron]pentacarbonylmolybdenum [2a-Mo $\left.(\mathrm{CO})_{5}\right]$}

This complex was prepared following reported procedure [7]. $\mathrm{Mo}(\mathrm{CO})_{6}(316.6 \mathrm{mg}, 1.18 \mathrm{mmol})$ and $\mathrm{Me}_{3} \mathrm{~N}=\mathrm{O}(131.6$ $\mathrm{mg}, 1.18 \mathrm{mmol}$ ) in an oven-dried 2-necked round-bottomed 
flask were dried under vacuum, and the flask was back-filled with nitrogen. $\mathrm{CH}_{2} \mathrm{Cl}_{2}(3 \mathrm{~mL})$ and $\mathrm{MeCN}(3 \mathrm{~mL})$ were added via syringes. After stirring at $\mathrm{rt}$ for $90 \mathrm{~min}$, the solution of $\mathbf{2 a}$ $(576.4 \mathrm{mg}, 1.18 \mathrm{mmol})$ in dry toluene $(4 \mathrm{~mL})$ in a roundbottomed flask was added to the 2-necked flask via cannula. The resulting mixture was stirred at $\mathrm{rt}$ for $6 \mathrm{~h}$, at which time TLC $\left(\mathrm{SiO}_{2}\right.$, hexanes/ether 1:1) indicated quantitative conversion. Solvents were removed under reduced pressure on a rotary evaporator and the residue was purified with flash column chromatography $\left(\mathrm{SiO}_{2}\right.$, pretreated with $5 \% \mathrm{Et}_{3} \mathrm{~N}$ in hexanes; hexanes/ether 1:1). Product 2a-Mo(CO) $)_{5}$ was obtained as deep purple crystals $(735.6 \mathrm{mg}, 86 \%): R_{f}=0.70$ (hexanes/ether 1:1); mp 190-192 ${ }^{\circ} \mathrm{C} ;{ }^{1} \mathrm{H}$ NMR $\left(\mathrm{CDCl}_{3}\right) \delta$ 7.75 (d, $1 \mathrm{H}, J=15.2 \mathrm{~Hz}, \mathrm{Ph}), 7.67-7.62$ (m, 2H, Ph), 7.48$7.40(\mathrm{~m}, 8 \mathrm{H}, \mathrm{Ph}), 7.36(\mathrm{dt}, 1 \mathrm{H}, J=9.2,0.4 \mathrm{~Hz}, \mathrm{Ph}), 7.05$ (ddd, $1 \mathrm{H}, J=9.2,8.0,1.2 \mathrm{~Hz}, \mathrm{Ph}), 4.42(\mathrm{~d}, 1 \mathrm{H}, J=2.8 \mathrm{~Hz}$, $\mathrm{H}-1$ or $\mathrm{H}-3), 4.40(\mathrm{~d}, 1 \mathrm{H}, J=2.4 \mathrm{~Hz}, \mathrm{H}-1$ or $\mathrm{H}-3), 3.91(\mathrm{t}$, $1 \mathrm{H}, J=2.8 \mathrm{~Hz}, \mathrm{H}-2), 1.57\left(\mathrm{~s}, 15 \mathrm{H}, \mathrm{Cp}^{*}-\mathrm{Me}\right) ;{ }^{13} \mathrm{C} \mathrm{NMR}$ $\left(\mathrm{CDCl}_{3}\right) \delta 210.7\left(\mathrm{~d}, J_{C P}=84.8 \mathrm{~Hz}, \mathrm{CO}\right), 206.1\left(\mathrm{~d}, J_{C P}=36.4\right.$ $\mathrm{Hz}, \mathrm{CO} \times 4), 138.8\left(\mathrm{~d}, J_{C P}=72.8 \mathrm{~Hz}, \mathrm{Ph}\right), 137.6\left(\mathrm{~d}, J_{C P}=\right.$ $145.6 \mathrm{~Hz}, \mathrm{Ph}), 136.6\left(\mathrm{~d}, J_{C P}=139.6 \mathrm{~Hz}, \mathrm{Ph}\right), 133.2\left(\mathrm{~d}, J_{C P}=\right.$ $48.8 \mathrm{~Hz}, \mathrm{Ph}), 132.5\left(\mathrm{~d}, J_{C P}=48.8 \mathrm{~Hz}, \mathrm{Ph}\right), 130.0\left(\mathrm{~d}, J_{C P}=\right.$ $176 \mathrm{~Hz}, \mathrm{Ph}), 128.7(\mathrm{Ph}), 128.6(\mathrm{Ph}), 128.6\left(\mathrm{~d}, J_{C P}=36.4 \mathrm{~Hz}\right.$, $\mathrm{Ph}), 128.1\left(\mathrm{~d}, J_{C P}=36.8 \mathrm{~Hz}, \mathrm{Ph}\right), 127.5\left(\mathrm{~d}, J_{C P}=145.6 \mathrm{~Hz}\right.$, $\mathrm{Ph}), 125.1$ (d, $\left.J_{C P}=42.4 \mathrm{~Hz}, \mathrm{Ph}\right), 88.3\left(\mathrm{C}^{\prime} 7^{\prime}\right), 87.3$ (d, $J_{C P}=$ $54.8 \mathrm{~Hz}, \mathrm{C}-3$ '), 78.9 (C-1 or C-3), 77.8 (C-1 or C-3), 67.3 (C-2 or $\left.\mathrm{Cp}^{*}\right), 66.9\left(\mathrm{C}-2\right.$ or $\left.\mathrm{Cp}^{*}\right), 10.5\left(\mathrm{Cp}^{*}-\mathrm{Me}\right) ;{ }^{31} \mathrm{P} \mathrm{NMR}$ $\left(\mathrm{CDCl}_{3}\right) \quad \delta$ 38.37; FAB-HRMS (NBA) calcd. for $\mathrm{C}_{36} \mathrm{H}_{31} \mathrm{FeMoO}_{5} \mathrm{P}(\mathrm{m} / \mathrm{z})\left[\mathrm{M}^{+}\right]$728.0313; found 728.0318.

[5-(Diethylphosphino)indenyl-pentamethylcyclopentadienyliron]pentacarbonylmolybdenum [2b-Mo(CO $\left.)_{5}\right]$

Following the procedure for the preparation of $\mathbf{2 a -}$

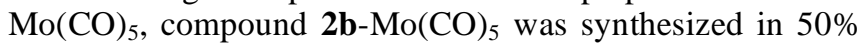
yield as a deep purple sticky solid: $R_{f}=0.52$ (hexanes/ether 100:1); ${ }^{1} \mathrm{H}$ NMR $\left(\mathrm{CDCl}_{3}\right) \delta 7.68(\mathrm{~d}, 1 \mathrm{H}, J=12.8 \mathrm{~Hz}, \mathrm{Ph})$, $7.42(\mathrm{~d}, 1 \mathrm{H}, J=8.4 \mathrm{~Hz}, \mathrm{Ph}), 7.04(\mathrm{t}, 1 \mathrm{H}, J=8.0 \mathrm{~Hz}, \mathrm{Ph})$, $4.45(\mathrm{~s}, 1 \mathrm{H}, \mathrm{H}-1$ or $\mathrm{H}-3), 4.40(\mathrm{~s}, 1 \mathrm{H}, \mathrm{H}-1$ or $\mathrm{H}-3), 3.89$ (s, 1H, H-2), 2.17-2.01 (m, 4H, $\mathrm{PCH}_{2}$ ), 1.65 (s, 15H, Cp*-Me), 1.21-1.04 (m, 6H, Me); ${ }^{13} \mathrm{C} \mathrm{NMR}\left(\mathrm{CDCl}_{3}\right) \delta 210.3\left(\mathrm{~d}, J_{C P}=\right.$ $84.8 \mathrm{~Hz}, \mathrm{CO}), 206.5\left(\mathrm{~d}, J_{C P}=36.8 \mathrm{~Hz}, \mathrm{CO} \times 4\right), 135.9(\mathrm{~d}$, $\left.J_{C P}=60.4 \mathrm{~Hz}, \mathrm{Ph}\right), 128.7\left(\mathrm{~d}, J_{C P}=36.4 \mathrm{~Hz}, \mathrm{Ph}\right), 127.2(\mathrm{~d}$, $\left.J_{C P}=133.6 \mathrm{~Hz}, \mathrm{C}-5\right), 122.1\left(\mathrm{~d}, J_{C P}=36.8 \mathrm{~Hz}, \mathrm{Ph}\right), 88.3(\mathrm{C}-$ 7'), $87.8\left(\mathrm{~d}, J_{C P}=54.4 \mathrm{~Hz}, \mathrm{C}-3\right.$ '), 78.6 (C-1 and C-3), 67.1 (C-2 or $\left.\mathrm{Cp}^{*}\right), 66.7\left(\mathrm{C}-2\right.$ or $\left.\mathrm{Cp}^{*}\right), 24.6\left(\mathrm{~d}, J_{C P}=91.2 \mathrm{~Hz}\right.$, $\left.\mathrm{PCH}_{2}\right), 23.9\left(\mathrm{~d}, J_{C P}=91.2 \mathrm{~Hz}, \mathrm{PCH}_{2}\right), 10.6\left(\mathrm{Cp}^{*}-\mathrm{Me}\right), 8.8$ $(\mathrm{Me} \times 2) ;{ }^{31} \mathrm{P} \mathrm{NMR}\left(\mathrm{CDCl}_{3}\right) \delta$ 26.66; FAB-HRMS (NBA) calcd. for $\mathrm{C}_{28} \mathrm{H}_{31} \mathrm{FeMoO}_{5} \mathrm{P}(\mathrm{m} / \mathrm{z}) \quad\left[\mathrm{M}^{+}\right]$632.0313; found 632.0318 .

\section{[5-(Dicyclohexylphosphino)indenyl-pentamethylcyclopen- tadienyliron]pentacarbonylmolybdenum $\left[2 \mathrm{~d}-\mathrm{Mo}(\mathrm{CO})_{5}\right]$}

Following the procedure for the preparation of $\mathbf{2 a -}$ $\mathrm{Mo}(\mathrm{CO})_{5}$, compound 2d-Mo(CO) $)_{5}$ was synthesized in $92 \%$ yield as a deep purple solid: $R_{f}=0.50$ (hexanes); mp 152-154 ${ }^{\circ} \mathrm{C} ;{ }^{1} \mathrm{H}$ NMR $\left(\mathrm{CDCl}_{3}\right) \delta 7.96(\mathrm{~d}, 1 \mathrm{H}, J=10.4 \mathrm{~Hz}, \mathrm{Ph}), 7.49$ (brs, $1 \mathrm{H}, \mathrm{Ph}$ ), 7.30 (brs, 1H, Ph), 4.62 (brs, $1 \mathrm{H}, \mathrm{H}-1$ or $\mathrm{H}-3$ ), 4.53 (brs, $1 \mathrm{H}, \mathrm{H}-1$ or H-3), 4.01 (brs, 1H, H-2), 2.42-0.99 (m, 22H, Cy), 1.79 (s, 15H, Cp*-Me); ${ }^{13} \mathrm{C} \mathrm{NMR}\left(\mathrm{CDCl}_{3}\right) \delta$ $210.4\left(\mathrm{~d}, J_{C P}=85.2 \mathrm{~Hz}, \mathrm{CO}\right), 207.4\left(\mathrm{~d}, J_{C P}=30.4 \mathrm{~Hz}, \mathrm{CO} \times\right.$ 4), $139.0\left(\mathrm{~d}, J_{C P}=60.8 \mathrm{~Hz}, \mathrm{Ph}\right), 127.1\left(\mathrm{~d}, J_{C P}=30.4 \mathrm{~Hz}, \mathrm{Ph}\right)$, $125.5\left(\mathrm{~d}, J_{C P}=30.4 \mathrm{~Hz}, \mathrm{Ph}\right), 123.6\left(\mathrm{~d}, J_{C P}=109.2 \mathrm{~Hz}, \mathrm{C}-5\right)$,
88.7 (C-7'), 88.4 (d, $\left.J_{C P}=48.4 \mathrm{~Hz}, \mathrm{C}-3^{\prime}\right), 78.8$ (C-1 or C-3), 77.4 (C-1 or C-3), 67.0 (C-2 or $\left.\mathrm{Cp}^{*}\right), 66.3$ (C-2 or $\left.\mathrm{Cp}^{*}\right)$, $36.8\left(\mathrm{~d}, J_{C P}=72.8 \mathrm{~Hz}, \mathrm{PCH}\right), 35.6\left(\mathrm{~d}, J_{C P}=72.8 \mathrm{~Hz}, \mathrm{PCH}\right)$, $28.6\left(\mathrm{CH}_{2}\right), 27.7\left(\mathrm{CH}_{2} \times 2\right), 27.4\left(\mathrm{CH}_{2}\right), 27.2\left(\mathrm{CH}_{2}\right), 27.1$ $\left(\mathrm{CH}_{2} \times 2\right), 27.0\left(\mathrm{CH}_{2}\right), 26.2\left(\mathrm{CH}_{2}\right), 26.1\left(\mathrm{CH}_{2}\right), 10.7\left(\mathrm{Cp}^{*}-\right.$ $\mathrm{Me}) ;{ }^{31} \mathrm{P}$ NMR $\left(\mathrm{CDCl}_{3}\right) \delta 46.5$; FAB-HRMS (NBA) calcd. for $\mathrm{C}_{36} \mathrm{H}_{43} \mathrm{FeMoO}{ }_{5} \mathrm{P}(\mathrm{m} / \mathrm{z})\left[\mathrm{M}^{+}\right]$740.1252; found 740.1259.

\section{[4-(Diphenylphosphino)indenyl-pentamethylcyclopentadie- nyliron]pentacarbonylmolybdenum $\left[1 \mathrm{a}-\mathrm{Mo}(\mathrm{CO})_{5}\right]$}

Following the procedure for the preparation of $\mathbf{2 a}$ $\mathrm{Mo}(\mathrm{CO})_{5}$, compound 1a-Mo(CO $)_{5}$ was synthesized. The compound could not be purified by crystallization and column chromatography; HPLC analysis indicated 4 compounds (roughly in a ratio of $1: 27: 70: 2$ ) but on TLC only one spot could be seen. Because the three impurities were in smaller quantities, part of NMR data could be assigned: $R_{f}=$ 0.60 (hexanes); ${ }^{1} \mathrm{H}$ NMR $\left(\mathrm{CDCl}_{3}\right) \delta 7.90-7.12(\mathrm{~m}, 13 \mathrm{H}, \mathrm{Ph})$, 4.26 (brs, $1 \mathrm{H}, \mathrm{H}-1, \mathrm{H}-2$ or H-3), 3.72 (brs, $1 \mathrm{H}, \mathrm{H}-1, \mathrm{H}-2$ or H-3), 3.66 (brs, 1H, H-1, H-2 or H-3), 1.49 (s, 15H, Cp*$\mathrm{Me}) ;{ }^{13} \mathrm{C}$ NMR $\left(\mathrm{CDCl}_{3}\right) \delta 211.2\left(\mathrm{~d}, J_{C P}=97.2 \mathrm{~Hz}, \mathrm{CO}\right)$, $206.1\left(\mathrm{~d}, J_{C P}=30.4 \mathrm{~Hz}, \mathrm{CO} \times 4\right), 136.9-120.2(\mathrm{Ph}$, could not be assigned), $92.9\left(\mathrm{~d}, J_{C P}=12.0 \mathrm{~Hz}, \mathrm{C}-3\right.$ ' or C-7'), $88.1(\mathrm{~d}$, $J_{C P}=12.0 \mathrm{~Hz}, \mathrm{C}-3$ ' or C-7'), 78.3 (C-1 or C-3), 77.7 (C-1 or C-3), 66.3 (C-2 or $\left.\mathrm{Cp}^{*}\right), 66.1$ (C-2 or $\left.\mathrm{Cp}^{*}\right), 10.3$ (Cp*-Me); ${ }^{31} \mathrm{P} \mathrm{NMR}\left(\mathrm{CDCl}_{3}\right) \delta$ 41.2; FAB-HRMS (NBA) calcd. for $\mathrm{C}_{36} \mathrm{H}_{31} \mathrm{FeMoO}_{5} \mathrm{P}(\mathrm{m} / \mathrm{z})\left[\mathrm{M}^{+}\right]$728.0313; found 728.0321.

[4-(Diethylphosphino)indenyl-pentamethylcyclopentadienyliron]pentacarbonylmolybdenum $\left[1 \mathrm{~b}-\mathrm{Mo}(\mathrm{CO})_{5}\right]$

Following the procedure for the preparation of $\mathbf{2 a}$ $\mathrm{Mo}(\mathrm{CO})_{5}$, compound $\mathbf{1 b}-\mathrm{Mo}(\mathrm{CO})_{5}$ was synthesized in $83 \%$ yield as a deep purple solid: $R_{f}=0.75$ (hexanes/ether $1: 1$ ); mp 110-112 ${ }^{\circ} \mathrm{C} ;{ }^{1} \mathrm{H}$ NMR $\left(\mathrm{CDCl}_{3}\right) \delta 7.43(\mathrm{~d}, 1 \mathrm{H}, J=7.2 \mathrm{~Hz}$, $\mathrm{Ph}$ ), 7.23 (brs, 1H, Ph), 7.01 (brs, 1H, Ph), 4.55 (s, 1H, H-1 or H-3), 4.35 (s, 1H, H-1 or H-3), 3.86 (s, 1H, H-2), 2.78$2.52\left(\mathrm{~m}, 2 \mathrm{H}, \mathrm{PCH}_{2}\right), 2.46-2.20\left(\mathrm{~m}, 2 \mathrm{H}, \mathrm{PCH}_{2}\right), 1.64(\mathrm{~s}, 15 \mathrm{H}$, $\left.\mathrm{Cp}^{*}-\mathrm{Me}\right), 1.42-1.10(\mathrm{~m}, 6 \mathrm{H}, \mathrm{Me} \times 2) ;{ }^{13} \mathrm{C} \mathrm{NMR}\left(\mathrm{CDCl}_{3}\right) \delta$ $210.6\left(\mathrm{~d}, J_{C P}=78.8 \mathrm{~Hz}, \mathrm{CO}\right), 206.3\left(\mathrm{~d}, J_{C P}=24.4 \mathrm{~Hz}, \mathrm{CO} \times\right.$ 4), $133.4\left(\mathrm{~d}, J_{C P}=109.2 \mathrm{~Hz}, \mathrm{C}-5\right), 131.6(\mathrm{Ph}), 126.9\left(\mathrm{~d}, J_{C P}\right.$ $=36.4 \mathrm{~Hz}, \mathrm{Ph}), 121.2\left(\mathrm{~d}, J_{C P}=30.0 \mathrm{~Hz}, \mathrm{Ph}\right), 90.4\left(\mathrm{~d}, J_{C P}=\right.$ $42.4 \mathrm{~Hz}, \mathrm{C}-3$ ' or C-7'), 88.1 (C-3' or C-7'), 78.2 (d, $J=12.0$ $\mathrm{Hz}, \mathrm{C}-1), 77.3$ (C-3), 67.3 (C-2 or Cp*), 65.8 (C-2 or $\left.\mathrm{Cp}^{*}\right)$, $21.6\left(\mathrm{~d}, J_{C P}=90.8 \mathrm{~Hz}, \mathrm{PCH}_{2}\right), 20.1\left(\mathrm{~d}, J_{C P}=85.2 \mathrm{~Hz}\right.$, $\left.\mathrm{PCH}_{2}\right), 10.7\left(\mathrm{Cp}^{*}-\mathrm{Me}\right), 9.3(\mathrm{Me}), 8.7(\mathrm{Me}) ;{ }^{31} \mathrm{P} \mathrm{NMR}$ $\left(\mathrm{CDCl}_{3}\right) \quad \delta$ 28.45; FAB-HRMS (NBA) calcd. for $\mathrm{C}_{28} \mathrm{H}_{31} \mathrm{FeMoO}_{5} \mathrm{P}(\mathrm{m} / \mathrm{z})\left[\mathrm{M}^{+}\right]$632.0313; found 632.0316.

\section{[4-(Dicyclohexylphosphino)indenyl-pentamethylcyclopent-} adienyliron]pentacarbonylmolybdenum [1d-Mo(CO $\left.)_{5}\right]$

Following the procedure for the preparation of $\mathbf{2 a -}$ $\mathrm{Mo}(\mathrm{CO})_{5}$, compound 1d-Mo(CO $)_{5}$ was synthesized in $87 \%$ yield as a deep purple solid: $R_{f}=0.80$ (hexanes); mp 80-82 ${ }^{\circ} \mathrm{C} ;{ }^{1} \mathrm{H}$ NMR $\left(\mathrm{CDCl}_{3}\right) \delta 7.67\left(\mathrm{dd}, 1 \mathrm{H}, J_{H P, H H}=16.8,6.4 \mathrm{~Hz}\right.$, $\mathrm{Ph}), 7.51(\mathrm{dd}, 1 \mathrm{H}, J=8.4,2.4 \mathrm{~Hz}, \mathrm{Ph}), 7.07$ (t, $1 \mathrm{H}, J=7.2$ $\mathrm{Hz}, \mathrm{Ph}), 4.66$ (d, 1H, $J=2.4 \mathrm{~Hz}, \mathrm{H}-1$ or $\mathrm{H}-3), 4.29$ (d, $1 \mathrm{H}, J$ $=2.4 \mathrm{~Hz}, \mathrm{H}-1$ or H-3), 3.90 (t, $1 \mathrm{H}, J=2.4 \mathrm{~Hz}, \mathrm{H}-2), 3.06-$ $2.94(\mathrm{~m}, 1 \mathrm{H}, \mathrm{PCH}), 2.85-2.75(\mathrm{~m}, 1 \mathrm{H}, \mathrm{PCH}), 2.47-0.84(\mathrm{~m}$, 20H, Cy), 1.59 (s, 15H, Cp*-Me); ${ }^{13} \mathrm{C} \mathrm{NMR}\left(\mathrm{CDCl}_{3}\right) \delta 210.6$ (CO), $207.7(\mathrm{CO} \times 4), 137.0(\mathrm{Ph}), 132.6(\mathrm{Ph}), 129.0(\mathrm{Ph})$, 120.1 (Ph), 94.1 (C-3' or C-7'), 88.0 (C-3' or C-7'), 78.4 (C1 and $\mathrm{C}-3), 66.2$ (C-2 or $\left.\mathrm{Cp}^{*}\right), 65.1$ (C-2 or $\left.\mathrm{Cp}^{*}\right), 40.1$ 
(PCH), $33.7(\mathrm{PCH}), 29.4\left(\mathrm{CH}_{2}\right), 28.8\left(\mathrm{CH}_{2}\right), 28.2\left(\mathrm{CH}_{2}\right)$, $27.4\left(\mathrm{CH}_{2} \times 5\right), 25.9\left(\mathrm{CH}_{2} \times 2\right), 10.3\left(\mathrm{Cp}^{*}-\mathrm{Me}\right) ;{ }^{31} \mathrm{P} \mathrm{NMR}$ $\left(\mathrm{CDCl}_{3}\right) \quad \delta$ 63.16; FAB-HRMS (NBA) calcd. for $\mathrm{C}_{36} \mathrm{H}_{43} \mathrm{FeMoO}_{5} \mathrm{P}(\mathrm{m} / \mathrm{z})\left[\mathrm{M}^{+}\right]$740.1252; found 740.1258.

General Procedures for Palladium-Catalyzed Allylic Alkylation Reaction

\section{Procedure A}

The pre-catalyst $\left[\mathrm{Pd}\left(\mathrm{C}_{3} \mathrm{H}_{5}\right) \mathrm{Cl}\right]_{2}(0.02$ eq) and a ligand $(0.05 \mathrm{eq})$ were combined in a 2-necked round-bottomed flask and flushed with nitrogen. Freshly distilled $\mathrm{CH}_{2} \mathrm{Cl}_{2}$ was then added via syringe and the mixture was stirred at $\mathrm{rt}$ for $1 \mathrm{~h}$. Allyl acetate 5 (1 eq) in $\mathrm{CH}_{2} \mathrm{Cl}_{2}$ was then added via cannula, dimethylmalonate $(\mathbf{6}, 3 \mathrm{eq}$ ) and BSA (3 eq) were added via syringes, and finally KOAc (0.1 eq) was added under positive nitrogen pressure. The reaction mixture was stirred at temperatures specified in Table $\mathbf{1}$ and monitored by GC-MS.

\section{Procedure B}

Ligand 2a and the pre-catalyst $\left[\mathrm{Pd}\left(\mathrm{C}_{3} \mathrm{H}_{5}\right) \mathrm{Cl}\right]_{2}$ in a ratio of 2.5/1 (amounts were calculated according to substrate to palladium ratios in Table 1) were combined in a 2-necked round-bottomed flask and flushed with nitrogen. Freshly distilled THF was added via syringe and the mixture was stirred at rt for $30 \mathrm{~min}$, after which allyl acetate $\mathbf{8}(1 \mathrm{eq})$ was added via syringe. To another 2-necked round-bottomed flask, $\mathrm{NaH}$ (2 eq) was introduced under positive nitrogen pressure and THF was added via syringe. The mixture was cooled on an ice bath, and dimethylmalonate $(6,2 \mathrm{eq})$ was then added via syringe over $30 \mathrm{~min}$. After stirring at $0{ }^{\circ} \mathrm{C}$ for $15 \mathrm{~min}$, the temperature was raised to $25{ }^{\circ} \mathrm{C}$ and stirred for $30 \mathrm{~min}$. This sodium malonate solution was transferred to the flask containing the catalyst and substrate $\mathbf{8}$ via cannula. The reaction mixture was stirred at rt and monitored by GC-MS.

\section{General Procedure for Palladium-Catalyzed Suzuki Coupling of Chlorobenzene with Phenylboronic Acid}

A 2-necked round-bottomed flask with a magnetic stirring bar and a reflux condenser were dried in an oven and cooled under nitrogen. Phenylboronic acid (1 eq), $\mathrm{Pd}_{2}(\mathrm{dba})_{3}$ (0.015 eq; dba, dibenzylideneacetone) and $\mathrm{Cs}_{2} \mathrm{CO}_{3}$ (2 eq) were added under positive nitrogen pressure. The flask with the condenser was switched to vacuum for about $10 \mathrm{~min}$ and then turned back to nitrogen carefully. Chlorobenzene (1 eq) was then added via syringe. A ligand (2a-e, 0.036 eq) in a round-bottomed flask was dried under vacuum overnight and the flask was then switched to nitrogen atmosphere carefully. Freshly distilled 1,4-dioxane was added to both flasks via oven-dried syringes. Finally, the ligand solution was added to the 2-necked flask via cannula. The reaction mixture was then heated to reflux and monitored by GC-MS.

\section{X-Ray Crystallography}

A suitable crystal of compound 2a (obtained by crystallization from hexanes at $-20{ }^{\circ} \mathrm{C}$ ) was rolled in epoxy resin and mounted on a glass fiber. An Enraf Nonius CAD-4 X-Ray diffractometer was the instrument used for the determination. The windows program WinGX was used as the interface for the solution and refinement of the model [9]. The data were first reduced and corrected for absorption using psi-scans [10], and then solved using the program SIR97 [11]. Two molecules of 2a constituted the asymmetric unit and both of these contained rotational disorder in the $\mathrm{Cp}^{*}$ rings $(60 / 40$ ratio for $\mathrm{Fe} 1$ and $70 / 30$ for Fe2, Fig. 1) which were accounted for using standard procedures available in the program SHELXL97 [12]. This sort of rotational disorder (29.3 and $38.6^{\circ}$ clockwise for the $\mathrm{Cp}^{*}$ ligands in $\mathrm{Fe} 1$ and $\mathrm{Fe} 2$ respectively, Fig. 1) in the $\mathrm{Cp}^{*}$ ligand has been previously observed and could be crystallographically imposed or nonrandom as is the case with 2a [13]. All non-hydrogen atoms were refined with anisotropic thermal parameters and the hydrogen atoms were refined at calculated positions with thermal parameters constrained to the carbon atom on which they were attached. Crystal data and final structural refinement parameters are listed in Table 4.

Table 4. Summary of Crystallographic Data for 2a

\begin{tabular}{|c|c|}
\hline & $2 a$ \\
\hline formula & $\mathrm{C}_{31} \mathrm{H}_{31} \mathrm{FeP}$ \\
\hline $\mathrm{fw}, \mathrm{g} \cdot \mathrm{mol}^{-1}$ & 490.38 \\
\hline cryst syst & triclinic \\
\hline space group & $\mathrm{P}-1$ \\
\hline$a(\AA)$ & $8.838(3)$ \\
\hline$b(\AA)$ & $11.952(4)$ \\
\hline$c(\AA)$ & $25.696(6)$ \\
\hline$\alpha(\operatorname{deg})$ & $100.70(2)$ \\
\hline$\beta(\operatorname{deg})$ & $90.35(3)$ \\
\hline$\gamma(\operatorname{deg})$ & $104.11(3)$ \\
\hline$V\left(\AA^{3}\right)$ & $2582.9(14)$ \\
\hline$Z$ & 4 \\
\hline$d_{\text {calc }}\left(\mathrm{g} \cdot \mathrm{cm}^{-3}\right)$ & 1.261 \\
\hline$\mu\left(\mathrm{mm}^{-1}\right)$ & 0.662 \\
\hline$\theta(\mathrm{deg})$ & $1.62-22.47$ \\
\hline$\lambda(\AA)$ & 0.71073 \\
\hline $\mathrm{T}(\mathrm{K})$ & 293(2) \\
\hline GOF & 1.037 \\
\hline${R_{1}}^{a}, \mathrm{wR}_{2}(I>2 \sigma(I))^{b}$ & $0.061,0.162^{c}$ \\
\hline
\end{tabular}

${ }^{a} \mathrm{R}_{1}=\Sigma|| F_{o}|-| F_{c}|| / \Sigma \mid F_{o}$

${ }^{b} \mathrm{wR}_{2}=\left[\sum\left[w\left(F_{\mathrm{o}}{ }^{2}-F_{\mathrm{c}}\right)^{2}\right] / \sum\left[w\left(F_{\mathrm{o}}^{2}\right)^{2}\right]\right]^{1 / 2}$

${ }^{c} \mathrm{~W}=1 /\left[\sigma^{2}\left(\mathrm{Fo}^{2}\right)+(0.0620 \mathrm{P})^{2}+2.9602 \mathrm{P}\right]$ where $\mathrm{P}=\left(\mathrm{Fo}^{2}+2(\mathrm{Fc})^{2}\right) / 3$.

\section{Supplementary Materials}

The images of ${ }^{1} \mathrm{H},{ }^{13} \mathrm{C}$ and ${ }^{31} \mathrm{P}$ NMR spectra for all new compounds can be found on pages 10-44 of this article. Crystallographic data for the structure analysis have been deposited with the Cambridge Crystallographic Data Centre, CCDC No. 672018 for compound 2a; copies of this information may be obtained free of charge from The Director, CCDC, 12 Union Road, Cambridge CB2 IEZ, UK (fax: +44 1223336 033; e-mail: deposit@ccdc.cam.ac.uk or http://www.ccdc.cam.ac.uk). 


\section{ACKNOWLEDGEMENTS}

Financial supports from US NSF (CHE-0647129), MTU Chemistry Department, and MTU Research Excellence Fund; the assistance from Mr. Jerry L. Lutz (NMR), Mr. Shane Crist (computation) and Mr. Dean W. Seppala (electronics); and an NSF equipment grant (CHE-9512445) are all gratefully acknowledged.

\section{REFERENCES}

[1] Hegedus, L. S. Transition Metals in the Synthesis of Complex Organic Molecules, University Science Books, Mill Valley, California, 1994.

[2] (a) Littke, A. F.; Dai, C. Y.; Fu, G. C. J. Am. Chem. Soc., 2000, 122, 4020-4028; (b) Barder, T. E.; Walker, S. D.; Martinelli, J. R.; Buchwald, S. L. J. Am. Chem. Soc., 2005, 127, 4685-4696; (c) Anderson, K. W.; Buchwald, S. L. Angew. Chem. Int. Ed., 2005, 44, 6173-6177.

[3] (a) Thimmaiah, M.; Fang, S. Tetrahedron, 2007, 63, 6879-6886; (b) Thimmaiah, M.; Luck, R. L.; Fang, S. J. Organomet. Chem., 2007, 692, 1956-1962.

[4] (a) Wechsler, D.; Rankin, M. A.; McDonald, R.; Ferguson, M. J.; Schatte, G.; Stradiotto, M. Organometallics, 2007, 26, 6418-6427; (b) Curnow, O. J.; Fern, G. M.; Hamilton, M. L.; Zahl, A.; van Eldik, R.; Organometallics, 2004, 23, 906-912; (c) Curnow, O. J.; Fern, G. M. Organometallics, 2002, 21, 2827-2829; (d) Curnow, O. J.; Fern, G. M.; Hamilton, M. L.; Jenkins, E. M. J. Organomet. Chem., 2004, 689, 1897-1910.

[5] (a) Tolman, C. A. Chem. Rev., 1977, 77, 313-348; (b) van Leeuwen, P. W. N. M.; Kamer, P. C. J.; Reek, J. N. H.; Dierkes, P. Chem. Rev., 2000, 100, 2741-2769.

[6] (a) Tolman, C. A. J. Am. Chem. Soc., 1970, 92, 2953-2956; (b) Cotton, F. A.; Darensbourg, D. J.; Ilsley, W. H. Inorg. Chem., 1981, 20, 578-583; (c) Davies, M. S.; Allen, G. W.; Aroney, M. J.; Hambley, T. W.; Pierens, R. K. J. Mol. Struct., 1994, 326, 81-91; (d) Palcic, J. D.; Baughman, R. G.; Golynskiy, M. V.; Frawley, S. B.; Peters, R. G. J. Organomet. Chem., 2005, 690, 534-538.

[7] van Assema, S. G. A.; de Kanter, F. J. J.; Schakel, M. Lammertsma, K. Organometallics, 2006, 25, 5286-5291.

[8] (a) Laurenti, D.; Feuerstein, L.; Pepe, G.; Doucet, H.; Santelli, M. J. Org. Chem., 2001, 66, 1633-1637; (b) Doucet, H.; Santelli, M. Synlett, 2006, 2001-2015.

[9] Farrugia, L. J.; J. Appl. Crystallogr., 1999, 32, 837-838.

[10] North, A. C. T.; Phillips, D. C.; Mathews, F. S. Acta Crystallogr. A, 1968, 24, 351-359.

[11] Altomare, A.; Burla, M. C.; Camalli, M.; Cascarano, G.; Giacovazzo, C.; Guagliardi, A.; Moliterni, A. G. G.; Polidori, G.; Spagna, R. J. Appl. Crystallogr., 1999, 32, 115-119.

[12] Sheldrick, G. M. SHELX-97, Programs for Crystal Structure Analysis (Release 97-2), University of Göttingen, Germany, 1998.

[13] (a) Weber, L.; Kleinebekel, S.; Lonnecke, P. Z. Anorg. Allg. Chem. 2002, 628, 803-809; (b) Ohki, Y.; Takikawa, Y.; Hatanaka, T.; Tatsumi, K. Organometallics, 2006, 25, 3111-3113; (c) Scherer, O. J.; Meiers, J.; Regitz, M.; Hofmann, M. A.; Karaghiosoff, K.; Wolmershauser, G. Z. Anorg. Allg. Chem., 2001, 627, 1532-1536; (d) Koch, B.; Scherer, O. J.; Wolmershauser, G. Z. Anorg. Allg. Chem., 2000, 626, 1797-1802; (e) Triki, S.; Berezovsky, F.; Pala, J. S.; Garland, M. T. Inorg. Chim. Acta, 2000, 308, 31-36; (f) Chavez, I.; Alvarez-Carena, A.; Molins, E.; Roig, A.; Maniukiewicz, W.; Arancibia, A.; Arancibia, V.; Brand, H.; Manriquez, J. M. J. Organomet. Chem., 2000, 601, 126-132; (g) Akita, M.; Sakurai, A.; Moro-Oka, Y. Chem. Commun., 1999, 101-102; (h) Weber, L.; Kaminski, O.; Quasdorff, B.; Stammler, H. G.; Neumann, B. J. Organomet. Chem., 1997, 529, 329-341; (i) Driess, M.; Pritzkow, H.; Winkler, U. J. Organomet. Chem., 1997, 529, 313-321; (j) Friedrich, G.; Scherer, O. J.; Wolmershauser, G. Z. Anorg. Allg. Chem., 1996, 622, 1478-1486; (k) Akita, M.; Kato, S.; Terada, M.; Masaki, Y.; Tanaka, M.; Morooka, Y. Organometallics, 1997, 16, 23922412; (1) Jonas, K.; Klusmann, P.; Goddard, R. Z. Naturforsch. B Chem. Sci., 1995, 50, 394-404; (m) Akita, M.; Terada, M.; Oyama, S.; Morooka, Y. Organometallics, 1990, 9, 816-825. 